\title{
Preparation, characterization, and X-ray crystal structure of a one-dimensional calcium-based coordination polymer with strong blue fluorescent emission
}

\author{
Rong-Xin Yuan ${ }^{\text {a }}$, Ren-Gen Xiong ${ }^{\text {a, }}$, Zhen-Feng Chen ${ }^{\text {a }}$, Xiao-Zeng You ${ }^{\text {a,* }}$, \\ Shie-Ming. Peng ${ }^{b}$, G.-H. Lee ${ }^{b}$ \\ ${ }^{a}$ Coordination Chemistry Institute, The State Key Laboratory of Coordination Chemistry, Nanjing University, 210093, Nanjing, China \\ ${ }^{\mathrm{b}}$ Department of Chemistry, National Taiwan University, Taipei, Taiwan
}

Received 5 February 2001; accepted 14 May 2001

\begin{abstract}
The hydrothermal reaction of 4-cyanobenzoic acid with $\mathrm{Ca}\left(\mathrm{ClO}_{4}\right)_{2} \cdot 6 \mathrm{H}_{2} \mathrm{O}$ yields the one-dimensional calcium-based coordination polymer $\left[\mathrm{Ca}(\mathrm{L})_{2}\left(\mathrm{H}_{2} \mathrm{O}\right)_{2}\right]_{n} \mathbf{1}$ (where $\mathrm{L}=4$-cyanobenzoic acid) with strong blue fluorescent emission, and its solid-state structure has been characterized by X-ray single-crystal diffraction studies. Crystal data for 1: monoclinic, space group P2/n, $a=7.154$ (2), $b=16.402$ (3), $c=7.549$ (2) $\AA$; $\beta=115.83(2)^{\circ} ; Z=2 ; R=0.0536$ for 1410 independent reflections with $I>2 \alpha(I)$. (C) 2001 Elsevier Science B.V. All rights reserved.
\end{abstract}

Keywords: Calcium complex; Crystal structure; Hydrothermal synthesis; Blue fluorescent emission

\section{Introduction}

The chemistry of the alkaline earth metals has until recently remained a largely underdeveloped area of the periodic table. There have been a few studies in recent years of the coordination chemistry of these metals in both aqueous and non-aqueous media [1-5]. Like magnesium, calcium is also a biologically essential element, and it has been suggested that these elements were in fact involved with some of the earliest forms of life because of their important role in DNA and protein synthesis [6-8]. They play an essential role in the activation of enzymes, complexed with nucleic acids, inside cells necessary for nerve impulse transmission, muscle contraction, and the metabolism of carbohydrates $[9,10]$. Although the carboxylate-bridged dimetallic unit has been the subject of extensive studies in mimetic bioinorganic chemistry, the dinuclear calcium model complex with carboxylate bridges has been very rarely reported [11]. Herein, we report the novel one-dimensional calcium-based coordination polymer $\left[\mathrm{Ca}\left(\mathrm{OCOC}_{6} \mathrm{H}_{4} \mathrm{CN}\right)_{2}\left(\mathrm{H}_{2} \mathrm{O}\right)_{2}\right]_{n} 1$ with a

\footnotetext{
${ }^{*}$ Corresponding author. Fax: +86-25-331-4502.

E-mail address: xyz@netra.nju.edu.cn (X.-Z. You).

${ }^{1}$ Also corresponding author.
}

basic dinuclear $\mathrm{Ca}$ unit, which was synthesized by using a hydro(solvo)thermal reaction of 4-cyanobenzoic acid with $\mathrm{Ca}\left(\mathrm{ClO}_{4}\right)_{2} \cdot 6 \mathrm{H}_{2} \mathrm{O}$ in a mixture of water, 2-butanol and pyridine. The synthetic conditions, methods of structure characterization and descriptions of the compound are presented.

\section{Experimental}

\subsection{Synthesis}

Chemicals and solvents in this work were purchased from Aldrich and used as received, apart from $\mathrm{Ca}\left(\mathrm{ClO}_{4}\right)_{2} \cdot 6 \mathrm{H}_{2} \mathrm{O}$ which was prepared by the reaction of $\mathrm{CaCO}_{3}$ and $\mathrm{HClO}_{4}$ in aqueous solution. The FT-IR spectrum as recorded in a solid $\mathrm{KBr}$ matrix in the range $4000-400 \mathrm{~cm}^{-1}$ on a Nicolet Inpact 170SX FT-IR spectrometer. Elemental analyses were performed on a Perkin-Elmer 240C elemental analyzer.

\section{2. $\left[\mathrm{Ca}\left(\mathrm{OCOC}_{6} \mathrm{H}_{4} \mathrm{CN}\right)_{2}\left(\mathrm{H}_{2} \mathrm{O}\right)_{2}\right]_{n} \mathrm{I}$}

Samples of $0.104 \mathrm{~g}(0.3 \mathrm{mmol}) \mathrm{Ca}\left(\mathrm{ClO}_{4}\right)_{2} \cdot 6 \mathrm{H}_{2} \mathrm{O}$, $0.088 \mathrm{~g}(0.6 \mathrm{mmol}) 4$-cyanobenzoic acid were placed in a 
thick Pyrex tube (ca. $20 \mathrm{~cm}$ long). After addition of 0.5 $\mathrm{ml}$ water, $2 \mathrm{ml}$ 2-butanol and $0.1 \mathrm{ml}$ pyridine, the tube was frozen with liquid $\mathrm{N}_{2}$, evacuated under vacuum and sealed with a torch. The tube was then heated at $120^{\circ} \mathrm{C}$ for $10 \mathrm{~h}$ to give pure colorless rod crystals of 1 in $68 \%$ yield based on 4-cyanobezoic acid. Anal. Calc. For $\mathrm{C}_{16} \mathrm{H}_{12} \mathrm{CaN}_{2} \mathrm{O}_{6}$ : C, 52.2; H, 3.3; N,7.6; Found: C, 52.4; $\mathrm{H}, 3.5$; N, 7.8. IR spectrum $\left(\mathrm{cm}^{-1}\right): 3400(\mathrm{~s}), 2220(\mathrm{~m})$, $1620(\mathrm{~m}), 1580(\mathrm{~s}), 1530(\mathrm{~s}), 1290(\mathrm{~m}), 860(\mathrm{~m}), 800(\mathrm{~s})$, 690(m).

\subsection{X-ray structure determination for $\mathbf{1}$}

The single crystal X-ray diffraction experiment was performed at room temperature using a SMART CCD diffractometer equipped with monochromated MoK $\alpha$ radiation $(\lambda=0.71073 \AA)$. A suitable crystal was quickly separated from the mother liquid and coated with epoxy. The unit cell parameters were based on the least-squares refinement of three-dimension centroids of 14100 reflections, and the intensity data were collected using a narrow frame method. Frames were integrated with the Siemens SaInT program. The Sadabs program absorption correction based upon redundant reflections was applied to the data set. Crystal data for $\mathbf{1}$ : monoclinic, space group P2/n, $a=7.154$ (2), $b=16.402$ (3), $c=7.549$ (2) $\AA$; $\beta=115.83(2)^{\circ} ; V=797.2(3) \AA^{3}$; $Z=2 ; R=0.0536, w R 2=0.1315$ for 1410 independent reflections with $I>2(I) \alpha$. Selected bond distances and angles are listed in Table 1.

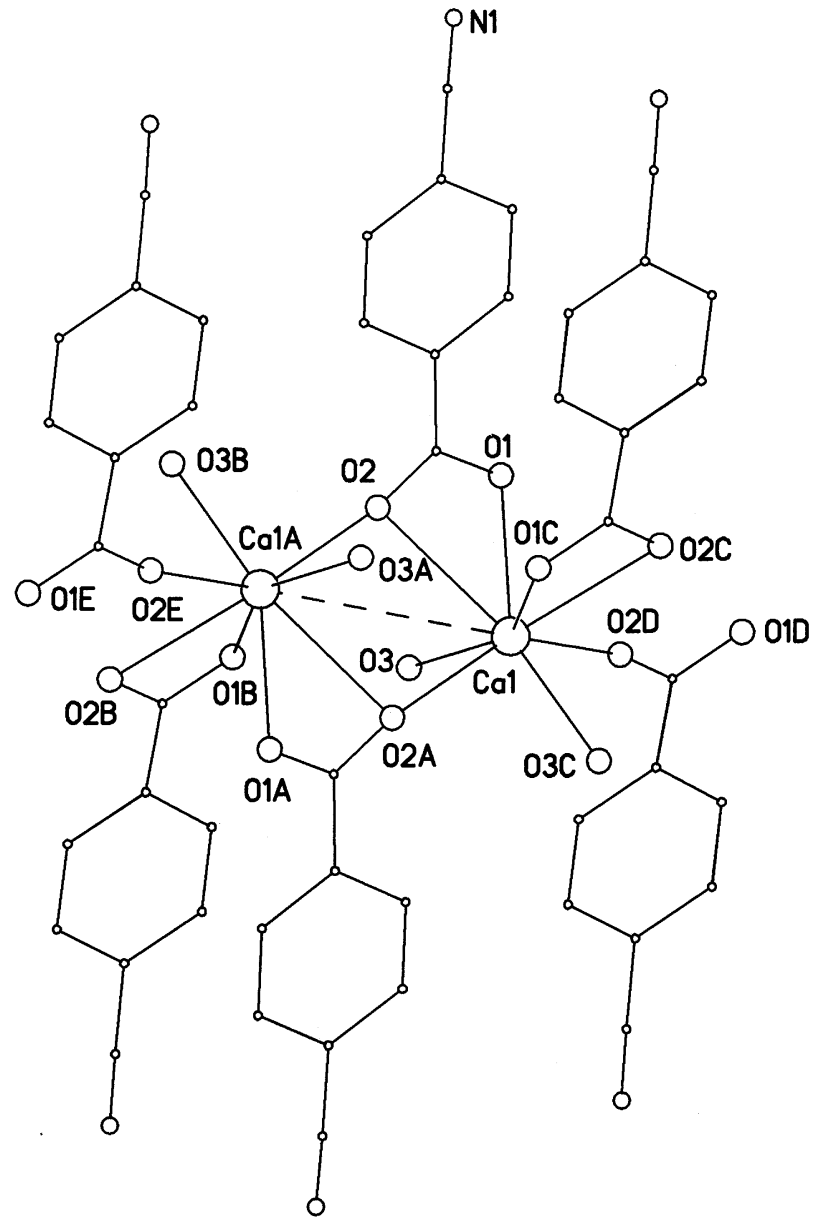

Fig. 1. The dinuclear $\mathrm{Ca}$ unit showing the eight-coordination about $\mathrm{Ca}$. The open circles with increasing size indicate $\mathrm{C}, \mathrm{O}, \mathrm{N}$ and $\mathrm{Ca}$, respectively.

Table 1

Selected bonds distances $(\AA)$ and angles $\left(^{\circ}\right)$

\begin{tabular}{lllc}
\hline $\mathrm{Ca}(1)-\mathrm{O}(2) \# 1$ & $2.316(2)$ & $\mathrm{Ca}(1)-\mathrm{O}(2) \# 2$ & $2.316(2)$ \\
$\mathrm{Ca}(1)-\mathrm{O}(3)$ & $2.375(3)$ & $\mathrm{Ca}(1)-\mathrm{O}(3) \# 3$ & $2.375(3)$ \\
$\mathrm{Ca}(1)-\mathrm{O}(1)$ & $2.453(3)$ & $\mathrm{Ca}(1)-\mathrm{O}(1) \# 3$ & $2.453(3)$ \\
$\mathrm{Ca}(1)-\mathrm{O}(2) \# 3$ & $2.756(3)$ & $\mathrm{Ca}(1)-\mathrm{O}(2)$ & $2.756(3)$ \\
$\mathrm{Ca}(1)-\mathrm{C}(1) \# 3$ & $2.920(4)$ & $\mathrm{Ca}(1)-\mathrm{C}(1)$ & $2.920(4)$ \\
$\mathrm{Ca}(1)-\mathrm{Ca}(1) \# 4$ & $4.023(15)$ & $\mathrm{Ca}(1)-\mathrm{Ca}(1) \# 1$ & $4.023(15)$ \\
$\mathrm{O}(1)-\mathrm{C}(1)$ & $1.270(4)$ & $\mathrm{O}(2)-\mathrm{C}(1)$ & $1.255(4)$ \\
$\mathrm{O}(2)-\mathrm{Ca}(1) \# 1$ & $2.316(2)$ & $\mathrm{N}(1)-\mathrm{C}(8)$ & $1.134(5)$ \\
$\mathrm{O}(2) \# 1-\mathrm{Ca}(1)-\mathrm{O}(2) \# 2$ & $139.60(13)$ & $\mathrm{O}(1)-\mathrm{Ca}(1)-\mathrm{O}(1) \# 3$ & $88.33(12)$ \\
$\mathrm{O}(2) \# 1-\mathrm{Ca}(1)-\mathrm{O}(3)$ & $\mathrm{O}(2) \# 1-\mathrm{Ca}(1)-\mathrm{O}(2) \# 3$ & $133.87(10)$ \\
$\mathrm{O}(2) \# 1-\mathrm{Ca}(1)-\mathrm{O}(3) \# 3$ & $85.61(9)$ & $\mathrm{O}(3)-\mathrm{Ca}(1)-\mathrm{O}(2) \# 3$ & $149.93(8)$ \\
$\mathrm{O}(3)-\mathrm{Ca}(1)-\mathrm{O}(3) \# 3$ & $\mathrm{O}(1)-\mathrm{Ca}(1)-\mathrm{O}(2) \# 3$ & $72.36(9)$ \\
$\mathrm{O}(2) \# 1-\mathrm{Ca}(1)-\mathrm{O}(1)$ & $\mathrm{O}(2) \# 1-\mathrm{Ca}(1)-\mathrm{O}(2)$ & $75.35(9)$ \\
$\mathrm{O}(3)-\mathrm{Ca}(1)-\mathrm{O}(1)$ & $\mathrm{O}(3)-\mathrm{Ca}(1)-\mathrm{O}(2)$ & $78.82(9)$ \\
$\mathrm{O}(3) \# 3-\mathrm{Ca}(1)-\mathrm{O}(1)$ & $\mathrm{O}(1)-\mathrm{Ca}(1)-\mathrm{O}(2)$ & $49.54(8)$ \\
$\mathrm{O}(2) \# 1-\mathrm{Ca}(1)-\mathrm{O}(1) \# 3$ & $116.39(15)$ & $\mathrm{O}(1) \# 3-\mathrm{Ca}(1)-\mathrm{O}(2)$ & $72.36(9)$ \\
$\mathrm{O}(2) \# 2-\mathrm{Ca}(1)-\mathrm{O}(1) \# 3$ & $124.37(8)$ & $\mathrm{O}(2) \# 3-\mathrm{Ca}(1)-\mathrm{O}(2)$ & $100.84(11)$ \\
$\mathrm{O}(3)-\mathrm{Ca}(1)-\mathrm{O}(1) \# 3$ & $85.79(10)$ & $\mathrm{O}(2) \# 1-\mathrm{Ca}(1)-\mathrm{C}(1) \# 3$ & $112.65(9)$ \\
$\mathrm{O}(3) \# 3-\mathrm{Ca}(1)-\mathrm{O}(1) \# 3$ & $149.41(9)$ & $\mathrm{O}(2) \# 2-\mathrm{Ca}(1)-\mathrm{C}(1) \# 3$ & $100.56(9)$ \\
$\mathrm{O}(2)-\mathrm{C}(1)-\mathrm{O}(1)$ & $87.21(8)$ & $\mathrm{O}(2)-\mathrm{C}(1)-\mathrm{C}(2)$ & $120.0(3)$ \\
$\mathrm{O}(1)-\mathrm{C}(1)-\mathrm{C}(2)$ & $124.37(8)$ & $\mathrm{O}(2)-\mathrm{C}(1) \mathrm{Ca}(1)$ & $70.01(19)$ \\
\hline
\end{tabular}

Symmetry transformations used to generate equivalent atoms: $\# 1-x,-y+1,-z ; \# 2 x+2,-y+1, z+1 ; \# 3 x+0.5, y,-z+0.5 ; \# 4-x+1,-y+1$, $-z+1$. 


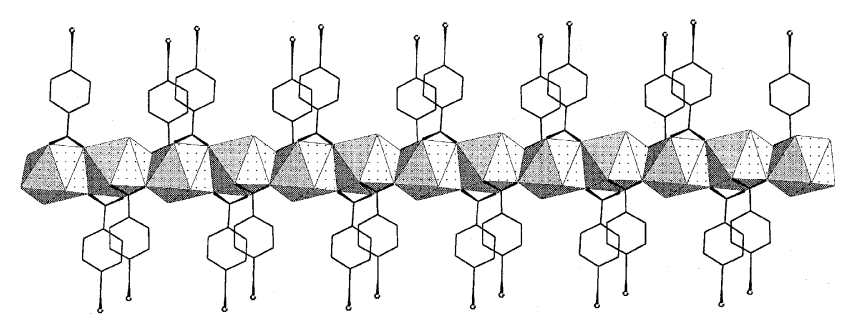

Fig. 2. A one-dimensional chain representation highlighting the $\mathrm{Ca}$ dodecahedron.

\section{Results and discussion}

The results of elemental analysis and the IR spectrum for 1 indicate that the reaction of $\mathrm{Ca}\left(\mathrm{ClO}_{4}\right)_{2} \cdot 6 \mathrm{H}_{2} \mathrm{O}$ with 4-cyanobenzoic acid yielded the one-dimensional infinite polymer. The IR spectrum shows a strong peak at $1620 \mathrm{~cm}^{-1}$, indicating that the carboxylic acid of the ligand is deprotonated (cf. $1700 \mathrm{~cm}^{-1}$ in the free 4-cyanobenozioc acid). The band at $2800-3100 \mathrm{~cm}^{-1}$ (b, s) corresponding to $v(\mathrm{O}-\mathrm{H})$ in the ligand is shifted to higher frequency $\left(3400 \mathrm{~cm}^{-1}\right)$. The medium peak at $2200 \mathrm{~cm}^{-1}$, related to $v(\mathrm{C}-\mathrm{N})$ is not changed, and it is illustrated that the cyano group is not coordinated.

In the crystal structure of $\mathbf{1}$ (Fig. 1), there is a centrosymmetric dinuclear unit, with all of the oxygen atoms of the carboxylates coordinated to the calcium

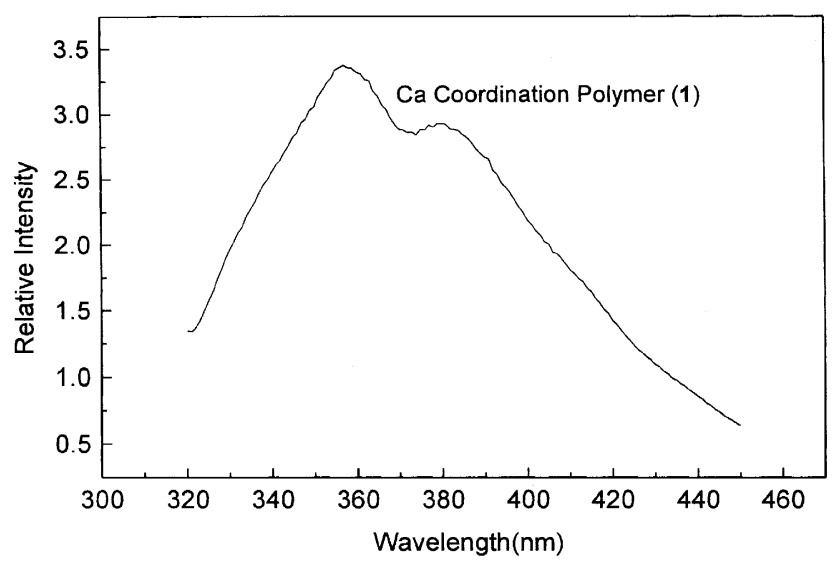

Fig. 4. The fluorescent emission spectrum of $\mathbf{1}$ in the solid state at room temperature.

centers in which carboxylate acts as tridentate ligand to link two $\mathrm{Ca}$ centers to give rise to a four-membered ring $[\mathrm{Ca}(1) \mathrm{O}(2) \mathrm{Ca}(1 \mathrm{~A}) \mathrm{O}(2 \mathrm{~A})]$. Two water molecules complete the eight-coordination about each $\mathrm{Ca}$, resulting in a distorted dodecahedral geometry (Fig. 2). Furthermore, the most distinctive structural feature of the complex 1 in the solid state is that it forms an infinite chain along the $b$-axis. Although the COO plane is not coplanar with the benzene ring, it appears that this configuration is stabilized by the intramolecular $\pi-\pi$

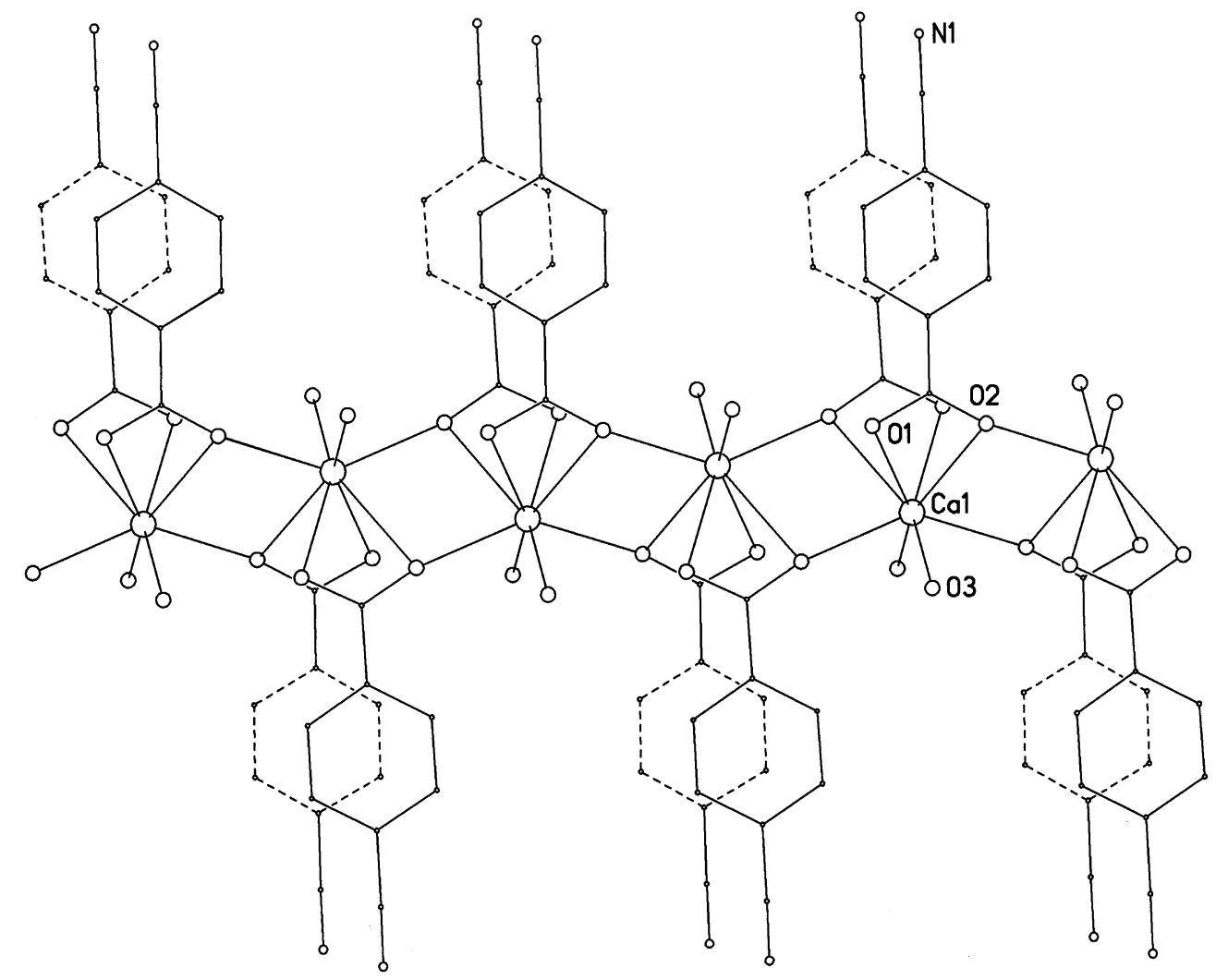

Fig. 3. A one-dimensional chain perspective view showing the $\pi-\pi$ stacking interaction between adjacent benzene rings. 
stacking interactions of the adjacent benzene rings with an approximate separation of 3.67-3.84 (Fig. 3). This structural feature is unexpected and quite different from those proposed previously for calcium carboxylate complexes [12-15].

As listed in Table 1, the Ca. . Ca distance of 4.0233 (15) $\AA$ is longer than that of the reported $\mathrm{Ca}$ dinuclear complexes [14-17]. A shorter $\mathrm{C}(1)-\mathrm{O}(2)$ bond (1.255 (4) $\AA)$ is located at the bridging oxygen, whereas another longer $\mathrm{C}(1)-\mathrm{O}(1)$ bond (1.270 (4) $\AA$ ) exists as a terminal ligand without bridging. This corresponds to what Bahl et al. [14] reported, that a longer $\mathrm{C}-\mathrm{O}$ bond distance for the bridging oxygen of carboxylate is due to the higher coordination of this oxygen. With the exception of the somewhat longer $\mathrm{Ca}(1)-\mathrm{O}(2)$ distance at 2.756 (3) $\AA$, other $\mathrm{Ca}-\mathrm{O}$ distances range from 2.316 to $2.453 \AA$, which is similar to the ranges observed for other seven-coordinate calcium carboxylate salts $\left[\mathrm{Ca}\left(\mathrm{CH}_{3} \mathrm{COO}\right)_{2}\left(\mathrm{H}_{2} \mathrm{O}\right)\right.$, 2.301-2.503 $\AA$, and $\mathrm{Ca}\left(\mathrm{CH}_{3} \mathrm{COO}\right)_{2}\left(\mathrm{CH}_{3} \mathrm{COOH}\right)\left(\mathrm{H}_{2} \mathrm{O}\right)$, $2.352-2.524 \AA][18,19]$. Other bond distances and angles are normal.

A salient feature of $\mathbf{1}$ is that it emits strong blue fluorescent light, as shown in Fig. 4. It is noteworthy that a similar emission was observed for the free ligand. Thus, the fluorescent emission of $\mathbf{1}$ can be tentatively assigned to intramolecular processes [20].

\section{Supplementary material}

X-ray crystallographic files in CIF format for compound $\mathbf{1}$ are available from Prof. S.-M. Peng.

\section{Acknowledgements}

This work was supported by the Major State Basic Research Development Program (Grant No.
G2000077500), and the National Natural Science Foundation of China.

\section{References}

[1] M.J. McCormick, K.B. Moon, S.R. Jones, T.P. Hanusa, J. Chem. Soc. Chem. Commum. (1990) 778.

[2] P.B. Hitchcock, M.F. Lappert, G. Lawless, B. Loyo, J. Chem. Soc. Chem. Commum. (1990) 1141.

[3] S.R. Drake, K.D. Anderson, M.B. Hursthouse, K.M.A. Malic, Inorg. Chem. 32 (1993) 1041.

[4] H. Westerhausen, Inorg. Chem. 30 (1991) 90.

[5] W.A. Wojtczak, P.F. Fleig, M.J. Hampden-Smith, Adv. Organomet. Chem. 40 (1996) 215.

[6] M. Abdulla, A. Behbehani, H. Dashli, Magnesium Health Disease (1989) 111.

[7] J.A. Piccirilli, J.S. Vyle, M.H. Caruthers, T.R. Cech, Nature 361 (1993) 85.

[8] [a] L.S. Beese, T.A. Steitz, EMBO J. 10 (1991) 25; [b] Z.-F. Chen, R.-G. Xiong, J. Zhang, J.-L. Zuo, Z. Guo, X.-Z. You, F.-K. Fun, J. Chem. Soc., Dalton Trans. (2000) 4013.

[9] H.G. Classen, S. Nowitski, H.F. Schimatschek, Magnesium Bull. 132 (1991) 39.

[10] T. Doyne, Adv. Protein Chem. 22 (1996) 600.

[11] A. Karipides, C. Miller, J. Am. Chem. Soc. 106 (1984) 1494.

[12] H. Einspahr, C.E. Bugg, Acta Crystallogr. Sect. B 37 (1971) 1044.

[13] H. Einspahr, C.E. Bugg, in: H. Siegel (Ed.), Metal Ions in Biological Systems: Calcium and Its Role in Biology, vol. 17, Marcel Dekker, Basel, 1984.

[14] A.M. Bahl, S. Krishnaswamy, N.G. Massand, D.J. Burkey, T.P. Hanusa, Inorg. Chem. 36 (1997) 5413.

[15] J.W. Yun, T. Tanase, S.J. Lippard, Inorg. Chem. 35 (1996) 7590.

[16] C.J. Carrel, H.L. Carrel, J. Erlebacher, J.P. Glusker, J. Am. Chem. Soc. 110 (1988) 8651.

[17] N. Ueyama, J. Takeda, Y. Yamada, A. Onoda, T. Okamura, Inorg. Chem. 38 (1999) 475.

[18] E.A. Klop, A. Schouten, P. Van Der Sluis, A.L. Spek, Acta Crystallogr. Sect. C 40 (1984) 51.

[19] E.A. Klop, A.L. Spec, Acta Crystallogr. Sect. C 40 (1984) 1817.

[20] [a] R.-G. Xiong, J.-L. Zuo, X.-Z. You, B.F. Abrahams, Z.-P. Bai, C.-M. Che, H.-K. Fun, Chem. Commun. (2000) 3897;

[b] R.-G. Xiong, J.-L. Zuo, X.-Z. You, H.-K Fun, S.S.S. Raj, Organometallics 19 (2000) 4183. 